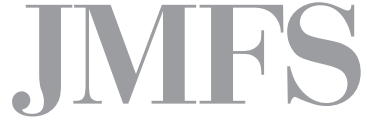

Journal of Management and Financial Sciences
Volume XII

Issue 39 (December 2019)

pp. 95-111

Warsaw School of Economics

Collegium of Management and Finance

Jarosław Trwoga

Bank Gospodarstw Krajowego

Institute of Finance

SGH Warsaw School of Economics

\title{
Direct financial instruments supporting foreign expansion of Polish companies used by Bank Gospodarstwa Krajowego
}

\begin{abstract}
Expansion to foreign markets usually implies the selection of an adequate financing facility that would fit a given transaction, as well as the specificity of a particular foreign market. This paper explores how Bank Gospodarstwa Krajowego (BGK) in its capacity of a state development bank funding the expansion of Polish business to other countries, i.e., exports and foreign direct investment projects carried out by Polish businesses or their foreign affiliates. The author's considerations focus on instruments offered by BGK, which provide direct financing, such as loans to foreign buyers and investment loans dedicated to projects carried out in other countries. Moreover, the paper discusses, inter alia, the current data for Polish exports, as well as selected transactions that BGK supported financially over the period 2015-2018.
\end{abstract}

Keywords: exports, foreign expansion, internationalisation, enterprises financing, BGK, banking sector JEL Classification Codes: G21, G34, F34, H74 


\section{Introduction}

Since Poland joined the European Union structures (2004) we have been witnessing an increasing intensity in the development of international relations established by Polish enterprises. Domestic companies have become more competitive and the economy more open to international exchange. The most frequently used measures of internationalisation include the share of exports in the GDP or the size of foreign direct investment (FDI) made by domestic companies abroad. According to data provided by GUS (Statistics Poland), Polish exports has increased over six-fold since 2000 in nominal terms and a quicker (compared to GDP dynamics) increase in exports substantially changed the structure of Polish GDP: the share of exports in the GDP in 2000 amounted to $18.5 \%$, while in 2017 it reached as much as $44.4 \%$.

The intensity of international links between enterprises depends, among others, on the market position of a given company and its internationalisation strategy (exports, resource-seeking expansion, capital expansion). At the same time, we need to stress that besides strategic, marketing or technical factors, the ability to finance foreign activities is very much relevant. Financial support to foreign expansion is key for economic policy of any country. However, in Poland such financial support has a relatively short track history compared to global leading exporters, such as the USA, Germany, China, Japan or South Korea. These countries for several dozen years already (some, e.g., the USA, even since the 1930s) have been running financial institutions (state-owned or private) whose goal is to financially support domestic investors, e.g., the American Export-Import Bank of the United States, German Kreditanstalt für Wiederaufbau IPEX Bank, Japan's Bank of Tokyo-Mitsubishi UFJ, Japan's Bank for International Cooperation, or the Korean Export-Import Bank of Korea. Export credit agencies also play a relevant role in supporting foreign projects. They not only act as underwriting institutions for banks providing export loans, but also insure domestic exporters, e.g., German Euler Hermes, Italian SACE S.p.A. or Japan's Nippon Export and Investment Insurance.

In the Polish financial sector, the role is played by institutions that make up the Polish Development Fund [Polski Fundusz Rozwoju]: ${ }^{1}$

- Bank Gospodarstwa Krajowego (BGK, 'Bank') established in 1924 - the state development bank of Poland, and

- Export Credit Insurance Corporation Joint Stock Company (KUKE) established in 1991 - the Polish export credit agency.

This paper presents BGK as a state development bank, which supports Polish enterprises in their foreign expansion. It discusses instruments used to directly finance Polish exports or foreign investment projects of Polish enterprises offered by the Bank. Recent works published in this area in Poland devoted to financial support from BGK were focused mainly on

1 In countries such as the United Kingdom, Canada, the USA, both functions (financial and insurance) are performed by one institution. 
de minimis guarantees [Andrzejak, 2017, Frańczuk, 2017]. Besides describing instruments used in direct financing, the paper gives examples of export contracts and cases of foreign direct investment of Polish enterprises supported by BGK. Given the goal of the paper and the adopted approach, further attention will focus on instruments used in direct financing of foreign expansion (covering exports and foreign direct investment) offered by BGK to Polish enterprises and their impact on the internationalisation of the Polish economy. ${ }^{2}$

\section{Theoretical scope of internationalisation of enterprises: models, types and motives behind foreign expansion}

Foreign expansion, also interpreted as internationalisation, covers a wide semantic field, for example: J. Rymarczyk defines foreign expansion as "any activity undertaken by domestic companies abroad" [Rymarczyk, 2004, p. 19], while M. Jarosiński interprets internationalisation as a "process in which relations with other entities are established to conclude sales and purchase agreements abroad or in relation with goals helping to improve international competitiveness" [Jarosiński, 2013, p. 19]. If we take a broader view on foreign expansion, we can divide it into three categories [Oczkowska, 2013, pp. 192-229]:

1. Product expansion (exports) - the simplest and the most popular form of foreign expansion of businesses consisting in selling goods and services manufactured or rendered by a domestic company. To pursue such activities abroad, we do not need to engage any substantial resources (financial or human) or have deep knowledge about a given market. Possible withdrawal does not imply a lot of effort, capital or time. In the literature this form of expansion may take two forms:

- passive exports (through intermediaries, without getting in touch with product buyers) - a solution deployed mainly by smaller companies, beginners on the international stage;

- direct exports - a more demanding solution (it requires, inter alia, knowledge about the market and the engagement of resources) which, nevertheless, gives control over foreign sales, bigger flexibility and usually generates higher margin for exporters because no intermediaries are involved.

2. Resource-seeking expansion (non-capital alliances) - economic activity resting on close cooperation with a foreign entity (e.g., licence agreements, franchising). Such collaboration may cover cooperation with suppliers, customers as well as competitors in each market.

3. Capital expansion - direct investment of a domestic company abroad, including mergers and acquisitions, development of distribution networks or the construction of a manufacturing plant.

2 For the needs of the paper, in relation with foreign expansion, foreign affiliates with capital holdings of Polish enterprises shall also be considered Polish. In this case, foreign expansion of a Polish economic entity remains the overarching goal and a foreign company (foreign affiliate) is the vehicle to achieve it. 
The above listed types of expansion usually happen one after another in a sequence; the deeper the engagement the higher the potential benefits and the risk of failure. Nonetheless, doing business outside of one's home country brings not only geographic diversification of sales but also helps in acquiring data and experience useful in further growth of a company in the domestic market. Interactions with foreign business partners/customers inform domestic companies not only how they could master their products or distribution channels but provide hints as to how they could improve work organisation or their manufacturing process. Proven foreign solutions put in place in the domestic market favour long-term growth of domestic business groups.

There are a number of business internationalisation theories, such as the Uppsala Model developed by researchers of the Uppsala University: Jan Johanson and Jan Erik Vahlne (1977) [Johanson, Vahlne, 1977, pp. 23-32], an innovative internationalisation model of S. Tamer Cavusgil (1980), and John H. Dunning's eclectic paradigm of international production (1980).

The Uppsala Model is one of the main and the best-known models describing internationalisation of companies. It was developed based on the analysis of Swedish companies operating in the 1970s. Findings of these studies derived from the behavioural theory and provided a picture of internationalisation processes. The authors came to a conclusion that internationalisation happens sequentially as a learning process that develops step by step in a specific sequence in accordance with the advancement of the process. Economic operators gradually expand abroad by systematically accumulating the knowledge about a market in question to eliminate uncertainty as to how the market works, as well as to overcome information shortages. In accordance with the Uppsala Model, internationalisation starts with exports, which initially are occasional and further evolve into a systematic activity carried out with the involvement of local agents (intermediaries). Such collaboration helps domestic firms in building long-term trade relationships with foreign partners, getting acquainted with the market, its perspectives and ramifications. Advancing engagement with the foreign market encourages companies to start contemplating the creation of own distribution channels or networks (sometimes competing with former business partners). Owning a distribution network with an office based abroad facilitates the transition to the next stage: placing manufacturing assets abroad within a foreign direct investment project. Such undertakings necessitate deep knowledge about the market as well as adequate capital/financial support that would allow launching manufacturing operations outside of the domestic market.

As observed by the authors of the Uppsala Model, a decision to carry out trade operations

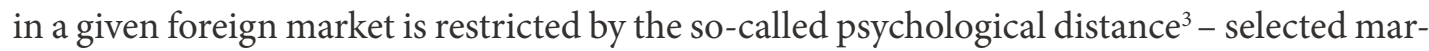
kets exhibit the biggest similarities to the domestic market, which is why the risk perceived for such markets is smaller. Decisive factors include the cultural circle, political system, language or economic development. Then, having accumulated necessary experience and knowledge,

3 Differences in legal, cultural, political, and competitive setting, which distort information exchange between a given company and the foreign market. 
enterprises are ready to get engaged with more demanding markets. Together with the increasing pool of knowledge and experience, risk and uncertainty in decision making concerning further steps in foreign expansion get reduced. Given advancing globalisation and the development of international links between enterprises, the authors extended the model with the so-called 'network approach', which assumes that each market in which an enterprise operates represents a network of mutual multilevel linkages and hence the internationalisation of an entity depends on its position in a given market environment [Barłożewski, 2017, p. 40]. Through the network of market linkages, a company may undergo internationalisation triggered by its local partners who have already decided to expand abroad. While the basic Uppsala Model stresses an individual role of an enterprise, the network model strives to grasp the conduct and decisions of groups of businesses that exert a mutual impact on one another. Advancing globalisation and technological progress have helped in reducing or eliminating numerous barriers influencing decisions on international business activity. Modern researchers of the internationalisation theory argue that the presence of 'born global' companies neutralises the assumptions of the Uppsala Model and creates an alternative path of internationalisation based on modern technological, communication, transport, and production solutions [Jarosiński, 2013, pp. 62-69]. Such companies already in the early stages of their development can operate in many markets, distant in geographic as well as cultural terms.

In the age of global challenges of facing economic operators all over the world, reasons behind going international are diverse and individual for each enterprise. They may depend on industry, jurisdiction/law (in the home or host country), development stage of a particular business, its financial standing, availability of funding, applied technology or management style. When trying to synthesize classifications of the determinants of internationalisation of companies discussed in the literature, we can distinguish the following motives: ${ }^{4}$

- market-driven - connected mainly with changes in demand and supply structure, i.e., inter alia, with a deteriorating trade situation in the domestic market, market saturation in a given industry, offered products, higher growth dynamics in foreign markets;

- cost-driven - reduction or optimisation of the costs of production is the overarching goal which can be linked with lower costs of raw materials, labour or geographic proximity of a given market which reduces the cost of transport;

- purchase-driven - they can be decisive when in the foreign market there are raw materials unavailable from natural sources in the domestic market or specific technological solutions, knowledge and/or production factors are more easily accessible;

- legal-political - linked with the institutional system of a given country; they impact the decision, e.g., concerning incentives (investment, duty, tax) available abroad and more favourable than at home, or more stable political and/or economic environment;

4 See, e.g., [Rymarczyk, 2012, pp. 181-192], [Witek-Hajduk, 2009, pp. 256-258], and [R. Oczkowska, 2013, pp. 98-105]. 
- financial - connected with access to financial resources (internal or external) necessary to carry out a given foreign project. In this aspect, BGK plays a crucial role by offering short- and long-term financial instruments supporting foreign operations.

Independently of the classification, individual motives are usually not unambiguously decisive and the decision to enter a foreign market as well as the choice of the operating format in this market result from a combination of all the above groups of determinants.

\section{Characteristics of the degree of diversification of Polish exports and internationalisation of Polish capital}

Active business presence in foreign markets is viewed as a measure of competitiveness at the micro and macro scale. Its key measures include not only the size of international trade but also the size of FDI made by domestic companies abroad. Below we can find the data for Poland for the period 2000-2017 (every five years) and the latest data available at the time of preparation of this article i.e., for 2017 :

Table 1. Selected data on Polish exports and internationalization of Polish capital in 2000-2017

\begin{tabular}{|l|r|r|r|r|r|}
\hline & 2000 & 2005 & 2010 & 2015 & 2017 \\
\hline Exports (bn of PLN) & 137.9 & 272.2 & 481.1 & 750.8 & 882.6 \\
\hline GDP (bn of PLN) & 744.4 & 983.3 & 1628.2 & 1789.7 & 1988.7 \\
\hline Exports share in GDP (\%) & 18.5 & 27.7 & 33.3 & 42.0 & 44.4 \\
\hline $\begin{array}{l}\text { Transactions linked with outward direct investment } \\
\text { from Poland (bn of PLN) }\end{array}$ & 0.074 & 4.40 & 18.5 & 18.8 & 10.4 \\
\hline
\end{tabular}

Source: own compilation based on data from GUS and NBP [National Bank of Poland].

In accordance with GUS statistics, the volume of Polish exports reached PLN 882.6 bn [GUS, 2018c] in 2017 and represented 44.4\% of the country's GDP. However, in the light of the methodology applied by the World Bank, the share of Polish exports in GDP amounted to $54.3 \%$ in 2017, being close to countries like Austria (53.9\%), Croatia (51.1\%), or Denmark (55.2\%) [www.worldbank.org, 2019]. On the other hand, according to the World Trade Organisation (WTO) data for 2017 Poland ranked $22^{\text {nd5 }}$ amongst top global exporters and its share in global exports was 1.3\% [www.wto.org, accessed: 13.04.2019]. Looking at WTO statistics for 2017, Poland's exports slightly outperformed countries such as Malaysia, Turkey or Norway, which were far ahead of Poland in 2004.

The geographic structure of Polish exports is a derivative of the engagement of Polish enterprises and their approach to regions or markets: slightly over $80 \%$ of domestic exports

5 According to World Trade Statistical Review 2005 - Poland ranked $31^{\text {st }}$ representing $0.8 \%$ share of global exports. 
are sold to the EU member states [www.stat.gov.pl/, accessed: 13.02.2019]. It means that the performance of Polish exports largely depends on the economic situation of the EU member states. Preliminary GUS data for 2018 [GUS, 2019] show that amongst ten largest export markets for Poland only one country (the USA) is situated outside of Europe, details are presented below:

Table 2. The largest export markets for Poland - preliminary GUS data for 2018

\begin{tabular}{|c|l|c|c|}
\hline No. & \multicolumn{1}{|c|}{ Country } & Exports (bn of PLN) & Share in total exports (\%) \\
\hline 1 & Germany & 264.8 & 28.2 \\
\hline 2 & The Czech Republic & 59.8 & 6.4 \\
\hline 3 & The United Kingdom & 58.2 & 6.2 \\
\hline 4 & France & 52.1 & 5.5 \\
\hline 5 & Italy & 43.2 & 4.6 \\
\hline 6 & The Netherlands & 42.5 & 4.5 \\
\hline 7 & Russia & 28.8 & 3.1 \\
\hline 8 & The USA & 26.2 & 2.8 \\
\hline 9 & Sweden & 26.0 & 2.8 \\
\hline 10 & Hungary & 25.1 & 2.7 \\
\hline
\end{tabular}

Source: own compilation based on GUS data.

Since 1990 the structure of Polish exports has not changed substantially (for 28 years Germany has been our main business partner). In 1990 the share of exports to Germany in total exports amounted to $25.1 \%$ [GUS, 2017], which testifies to substantial regional dependence of Polish exports and deep unwillingness amongst Polish companies to export to non-European countries. Polish businesses focus their activities on markets they consider safe, tested and stable, such as the European markets. Their approach results, inter alia, from the absence of experience in dealing with more distant markets or financial restrains. Importantly, Polish economy maintains relatively low labour costs $\left(6^{\text {th }}\right.$ ranking position amongst the lowest costs in the EU in 2016) [Eurostat, 2017], which is why the country exports many semi-finished products and low processed goods. Fostering the stability of Polish exports is not the only crucial area for the Polish economy; we should also look for new markets for Polish products. Domestic entrepreneurs can easily finance their exports to developed countries because in most instances business collaboration is based on trust and trade credit, while the role of banks is limited to the provision of settlement services. In the case of both higher risk markets as well as new foreign markets, institutional support is needed to ensure financing for foreign transactions.

Over time, increasingly more Polish enterprises decide to expand to foreign markets and direct their outward foreign investment abroad to engage into acquisitions or greenfield projects in other countries. At present, there are many companies in Poland which not only operate internationally but seek to become global companies (e.g., state-owned companies: KGHM, Orlen or private ones, such as Amica, Boryszew, Nowy Styl, Asseco or Wielton). Despite a relatively low value of investments made by Polish companies abroad, globally 
Poland remains the biggest foreign investor in Central and Eastern Europe. Polish outward direct investments abroad in 2017 reached PLN 10.4 bn, out of which PLN 3.1 bn was invested in shares and other forms of capital holdings, PLN 3.3 bn in reinvested profit and PLN 4.1 bn in debt securities [NBP, 2018]. Compared to 2016, the total value of transactions dropped by PLN 35.3 bn, i.e., by $77.1 \%$ mainly due to the change in the structure of investment funds' assets triggered by changes in tax schemes applied to investment funds ${ }^{6}$ in 2016 and the base effect connected with it, as well as a smaller - compared to previous years - scale of mergers, acquisitions and other foreign investment projects carried out by Polish companies.

Similarly to exports, geographic structure of Polish FDI is dominated by the EU (56.0\%). Remarkably, in 2017 most capital was invested in Sweden (PLN 7.2 bn) and Luxembourg (PLN 4.0 bn). It does not mean Polish investors were specifically interested in greenfield investment projects or acquisitions in these countries but it should be attributed to a single transaction linked with introducing order to the organisational structure of a business group in telecommunications (the change came as a result of the liquidation of the earlier existing organisational structures used for tax optimisation purposes) [NBP, 2018b]. In addition, in 2017 high value Polish investment projects were reported in Canada (PLN 1.7 bn) and Norway (PLN 1.0 bn) with simultaneous cases of disinvestment in Cyprus (PLN -6.9 bn) - (we need to bear in mind that the volume of invested capital is not identical with the volume of investments).

The number of foreign affiliates of Polish enterprises can be viewed as another measure of internationalisation. According to GUS data broken down by PKD (Polish Code List of Classification of Businesses), at the end of 2016 [GUS, 2018] 1,716 Polish economic operators had capital holdings in 3,897 affiliates abroad. Most of them originated from the food processing industry (600 Polish companies had 1,222 foreign affiliates), wholesale and retail trade ${ }^{7}$ (373 Polish enterprises owned 805 foreign firms), and construction (210 Polish enterprises with 308 foreign affiliates). In total, foreign affiliates owned by businesses based in Poland were scattered across 117 countries (with $63.1 \%$ of all foreign affiliates of Polish companies situated in $27 \mathrm{EU}$ member states). When it comes to the number of affiliates per country, the neighbouring countries prevail hosting 1,744 foreign affiliates ( $44.8 \%$ of the total stock); most of them registered in Germany (562), the Czech Republic (289), Ukraine (288), and Russia (245) [GUS, 2018].

The overall picture presented by the above data informing about activities performed by Polish enterprises abroad confirms the thesis about Polish companies being cautious in their approach to investing/concluding transactions outside of Europe and focusing mainly on the neighbouring markets. The key role in changing these trends should be played by institutions brought together in the Polish Development Fund, above all BGK as the state development bank offering financing for export activities and foreign expansion of Polish enterprises.

\footnotetext{
6 Funds gave up portfolio investments abroad, however, they continued investing in the same businesses through domestic companies. The NBP interpreted these investment projects as direct investments.

7 Including the repair of vehicles.
} 


\section{Integrated system of financial support for foreign expansion of Polish companies}

At present there are some public institutions in Poland which support Polish enterprises at different stages of their foreign expansion. Total support in this area is coordinated by the Ministry of Entrepreneurship and Technology with some involvement of the Ministry of Foreign Affairs. Measures adopted by the Polish government over the years 2016-2017 with the view to reorganise domestic development institutions brought together the following public bodies responsible to a different extent for supporting exports and expansion under the umbrella of the newly established Polish Development Fund:

- Polish Agency for Enterprise Development (Polish abbr. PARP);

- Industrial Development Agency JSC (Polish abbr. ARP);

- Polish Investment and Trade Agency JSC (Polish abbr. PAIH) formerly PAIZ [Polish Agency for Foreign Investment];

- Export Credit Insurance Corporation JSC [KUKE], and

- Bank Gospodarstwa Krajowego.

One of the principal goals of the Polish Development Fund Group is to intensify the internationalisation of Polish enterprises. The main burden connected with the implementation of this goal rests on BGK in cooperation with KUKE. Public bodies, such as PARP, ARP, or PAIH are expected to carry out information and promotional activities. Polish entrepreneurs expect organisational support in dealing with legal and institutional matters in foreign markets as well as information about tenders advertised in other countries, investment and/or trade opportunities. Equally important is the creation of a positive image of the Polish economy as a stable trade and investment partner.

\section{The role of Bank Gospodarstwa Krajowego in supporting foreign expansion of Polish enterprises}

Despite its long track history, export supporting as a role of the Bank was explicitly stated as late as in 2009 (following the adoption of the Government Programme for Exports Support $)^{8}$ and intensified after 2014. In 2014, the Bank extended short- and long-term export credits to the total value of PLN $184 \mathrm{~m}$, in 2015 loans reached PLN $571 \mathrm{~m}$, plus additional PLN 715 m dedicated to foreign expansion, while in 2017 the total amount spent on

8 On 28 July 2009 the Council of Ministers of the Republic of Poland adopted the Government Programme for Exports Support by granting loans from Bank Gospodarstwa Krajowego to foreign buyers of Polish goods and services or their banks with insurance protection of Export Credit Insurance Corporation S.A.. Next, on 12 December 2012 the name was changed to 'Financial Exports Support', and on 11 May 2015 the scope of available short-term instruments was extended. 
exports financing and foreign expansion amounted to PLN $1,800^{9} \mathrm{~m}$ [BGK, Annual reports for 2014; 2015; 2017].

When this paper was being written, Polish enterprises received support from BGK to projects located across 62 countries ${ }^{10}$ [www.media.bgk.pl, communication of 11.03.2019], offered, depending on the specificity of a particular transaction, as indirect (trade finance instruments, credits extended to importer's bank), as well as direct financing (loans to foreign buyers, long-term loans dedicated to foreign expansion, purchase of receivables) [www.bgk.pl, accessed 21.03.2019].

Usually Polish exporters seek financial support from financial institutions to finance or settle contracts with foreign partners, mainly in the EU market. They expect BGK to help them finance exports to markets exhibiting a higher risk, specifically in countries where: a) the scale of Polish exports is disproportionate to the potential of both economies, e.g., India, Brazil, African countries (e.g., Kenya, Ethiopia), b) political and economic situation is unstable, e.g., Russia, Ukraine, Georgia, and Turkey. Commercial banks based in Poland in most cases refrain from financing projects targeting such countries. Regarding that, BGK fills this gap in the Polish banking sector and is an example of the active role of the state in the economy.

It grants short- and long-term export credits secured by the KUKE insurance policy under the Government Programme for Exports Support adopted to intensify Polish exports and help Polish enterprises in getting access to foreign projects, which, together with the product and technical offer, must include financing solutions. Within the framework of the above-mentioned programme, by the end of 2016 BGK granted support amounting to PLN 2, $318 \mathrm{~m}$ to export contracts concluded by Polish enterprises for the total amount exceeding PLN 3 bn [BGK Annual Report, 2017]. In addition to funding export transactions, BGK acts as the administrator of the DOKE [Export Loan Subsidies] Programme [Act of 08.06.2001, Dz. U. No. 73, item 762], i.e., a system that stabilises export credit interest rates by subsidising interest rates charged on export credits by commercial banks. The programme is a form of export support addressed mainly to exporters of investment goods, for transactions financed with a repayment period not shorter than 2 years. Such transactions can receive official financing support only at fixed CIRR rates (Commercial Interest Reference Rates) set on the $15^{\text {th }}$ of each month by the OECD Secretariat. These rates reflect minimum interest rates that can be applied to export credits so that they could get official support. Since the introduction of the subsidies scheme, BGK granted in total 49 promissory notes for export credits financing export contracts the total value of USD 1, $446 \mathrm{~m}$, EUR $901.3 \mathrm{~m}$, NOK $380.0 \mathrm{~m}$, CAD $165.7 \mathrm{~m}$, and GDP $15.7 \mathrm{~m}$ [BGK,

9 To compare: Ceska Exportni Banka in 2017 supported Czech exporters/investors to the total amount of ca. PLN 715 m (PLN 336 m in 2016) [CEB, Annual Report for 2017, p. 23], Hungarian Magyar Export-Import Bank the equivalence of PLN 3.5 bn (data for 2016, do not include re-financing instruments for Hungarian commercial banks), [MEIB, Investor Presentation, p. 7]

10 In its annual report for 2016, the Bank informed that in 2015-2016 the number of countries in which BGK supported foreign activities of Polish enterprises doubled, reaching 42 countries at the end of 2016 [BGK, Annual Report for 2016, p. 21]. 
Annual Report 2016]. ${ }^{11}$ Whether credits are covered by the export financing programme or by the DOKE programme they must meet criteria specified in the so-called OECD consensus [www.oecd.org, 2019] ${ }^{12}$ (e.g., export credit may finance up to $85 \%$ of the contract value, ${ }^{13}$ credit should be paid back in quarterly or six month instalments). Furthermore, there is also additional requirement concerning Polish-origin components under the export contract, it should account for minimum $40 \%$ of the value of the export contract [www.bgk.pl, accessed: 15.04.2019].

In general, banks operating in the Polish market which support foreign expansion of domestic companies usually do not accept foreign assets as the principal form of collateral; they are interested in assets based in Poland. BGK secures credits dedicated to broadly understood internationalisation, primarily with foreign assets. This is how BGK actively supports Polish exporters as well as domestic enterprises which carry out investment projects abroad (including acquisitions). BGK's offer covers short-term as well as long-term instruments. The government programme offers mainly indirect instruments (such as the letter of credit, buyer's bank credit) to finance exports (product expansion) for smaller value projects/contracts and direct instruments, the so-called buyer's credit or purchase receivables for bigger investment projects. This is how BGK supports diverse export contracts run by Polish exporters. When it comes to buyer's credit, it can be taken out by private or public entities, as well as a foreign government. Within the offered instruments, the Bank takes on the settlement risk of a contract/project - the Polish enterprise is the beneficiary of disbursed funds, while the credit is drawn by the foreign operator (importer or its bank). Such a risk makes an inherent component of trade transactions and bank assistance is the more valuable to enterprises the less they know about, e.g., their foreign business partner, business practices in each country or economic regulations. If BGK gets involved on the side of the Polish company, the risk of not being paid gets largely reduced.

Besides direct export support instruments delivered mainly under the government programme, BGK also offers direct investment financing to Polish enterprises dedicated to the internationalisation of Polish capital. For such solutions, BGK offers long-term financing (dependent on the specificity of a given transaction) to Polish enterprises, their foreign affiliates or joint venture companies with Polish capital. The above-mentioned instruments are not covered by OECD consensus principles or requirements concerning Polish origin of goods and services, the most important is the engagement of a Polish company in a project located abroad. This is how BGK can finance, inter alia, foreign mergers and acquisitions or other investment projects, such as building manufacturing plants or distribution networks abroad.

11 Annual Report for 2017 does not include this information.

12 The Arrangement on Officially Supported Export Credits (OECD Consensus) provides a framework for financing export transactions in OECD member countries. These are credits granted for 2 years and more. The main goal of the document lies in creating a level playing field for competition amongst exporters based on quality and price of exported goods and services rather than on more favourable support terms offered by individual governments. Selected sectors, e.g., shipbuilding, civil aerospace, nuclear energy plants, renewable energy projects or rail transport are covered by additional agreements that identify the framework for financing these sectors.

${ }^{13}$ In addition, financing may include local costs up to $30 \%$ of total exports, i.e., exports from countries other than the importer's country. 


\section{Financial instruments of direct support to foreign expansion offered by BGK: structure and examples of transactions}

For the purpose of this paper the author has collected data on selected foreign projects/ contracts of Polish enterprises financed directly by BGK, broken down into export credits and investment credits dedicated to capital expansion of Polish enterprises.

\section{Export finance}

So far, the biggest foreign project which has received direct financing (buyer's credit) under the government Financial Exports Support Programme consisted in the financing of an Indonesian state-owned company PT Perusahaan Listrik Negara (Persero) in relation with the export contract concluded with Rafako S.A. for the construction of two steam blocks on the island of Lombok. In accordance with the loan agreement signed on 21.02.2018, BGK will provide financing totalling up to EUR $80.8 \mathrm{~m}$ (the loan has been secured with a KUKE insurance policy). The value of export contract for Rafako amounted to EUR $70.3 \mathrm{~m}$ [www.rafako. pl, accessed: 12.02.2019] and assuming that minimum 40\% of the value of the contract shall originate from Poland, exports to Indonesia (solely under the Rafako contract) may potentially increase (provided that the current exports remain stable) over the next 3 years ${ }^{14}$ by ca. PLN $115 \mathrm{~m}$ (according to GUS data, Polish exports to Indonesia reached PLN $441.4 \mathrm{~m}$ in 2017).

Another concrete example of financial support to exports extended by BGK is the financing of the construction of a shopping centre in Grodno [www.unibep.pl, accessed: 15.02.2019] - a loan granted to the Belarusian company Trinity Invest totalled EUR $55 \mathrm{~m}$. Financing was secured by, inter alia, a KUKE insurance policy in relation with an export contract concluded by the Polish construction company, Unibep S.A. In accordance with GUS data, Polish exports to Belarus amounted to PLN 5.6 bn in 2017 (0.63\% of total Polish exports) [www.stat.gov.pl, accessed: 22.02.2019]; BGK support given to specific types of activities helps in increasing the value of Polish exports to Belarus over the time of the project.

A similar project supported by BGK with a loan extended to the foreign buyer is carried out in Ukraine. The loan agreement signed in 2018 between BGK and the Ukrainian company LLC Martin provides financing for the turnkey construction project of a shopping and leisure centre in the Ukrainian capital. The net value of the contract for the Polish contractor totalled EUR $34.6 \mathrm{~m}$ [www.unibep.pl, accessed: 02.03.2019]. The loan extended by BGK is part of the growing trend of Polish exports to Ukraine and might be seen as an example for other Polish companies interested in developing their activities in this country.

${ }^{14}$ In accordance with the contract delivery terms. 


\section{Financing internationalisation of Polish capital}

In September 2017 OT Logistics S.A. (one of the best recognisable Polish brands in logistics), after having agreed it with other shareholders and with the support of BGK financing, took over the control of Luka Rijeka company - the operator of the biggest port in Croatia. Financing the increase of the Polish company's shares in Luka Rijeka was feasible as a result of the loan extended by BGK. The loan for OT Logistics S.A. amounted to PLN $125 \mathrm{~m}$ out of which PLN $46.6 \mathrm{~m}$ was earmarked for the purchase of additional stocks (11.75\%) of the Croatian company [www.otlogistics.com.pl, accessed: 11.02.2019] and PLN $10.7 \mathrm{~m}$ was spent on the tender offer for Luka Rijeka shares advertised by the Polish company. According to NBP data, direct foreign transactions in Croatia in 2016 totalled PLN $459 \mathrm{~m}$. The taking of operating control over the port in Rijeka by OT Logistics with the support of BGK will increase the engagement of the Polish capital in this country. In addition, in accordance with the strategy pursued by the Polish company, the transaction will lead to more efficient management of the port in Rijeka, the development of the Baltic-Adriatic transport route, as well as the development of a comprehensive offer for the customers of OT Logistics in the markets of Central and Eastern Europe [OT Logistics przejmuje chorwacki port, 2017].

Grupa Boryszew (Boryszew Group) is one of the biggest industrial groups in Poland specialising in the manufacturing of components for automotive industry, non-ferrous metals processing, and industrial chemistry. The Group's production plants can be found in Europe, Asia, South and North Americas. Financial support granted by BGK in June 2015 was dedicated to help Grupa Boryszew in increasing the production of components for global manufacturers in the automotive industry. In accordance with the loan agreement for EUR $10 \mathrm{~m}$, BGK financed the construction of a production plant in Mexico and the extension of its plants in China and in India - the loan was fully secured abroad for the first time ever in the Polish banking sector [BGK, communication of 15.06.2015].

Another example of the support to the internationalisation of Polish capital is the financing of the construction of a hotel in Edinburgh. The budget of the investment project was ca. GBP $14 \mathrm{~m}$ out of which GBP $8.5 \mathrm{~m}$ was covered by a BGK loan [Firma $z$ Chojnic podbija światowe rynki, 2017]. The bank financed the British special purpose vehicle, a subsidiary of the Polish family company Polcom for 12 years significantly contributing to its capital expansion. In addition to debt support from BGK, the project was also supported by the Foreign Expansion Fund managed by the PFR TFI (the Fund took up 49\% of shares in the special purpose vehicle constructing the hotel). ${ }^{15}$ The hotel was built using modular technology, which allowed completing the investment project within just 12 months. Importantly, besides the internationalisation of Polish capital (the hotel in the capital of Scotland was the first one in the United Kingdom owned by a Polish company) exports of goods and services

${ }^{15}$ FEZ acts as a passive investor and funds invested by FEZ are usually expected to be returned after 5-7 years. 
was very important, as $80 \%$ of construction materials originated from Poland. Financing extended to the hotel which opened in November 2017 is an example of a financial facility which combines debt and capital financing. This is also a flagship project of Polish business; it promotes not only innovative Polish technical thought but also key industries to the Polish economy: construction and furniture.

Other projects in the hotel industry supported by BGK including hotels in Tbilisi (2016) [KUKE, communication of 07.04.2017] and Moscow (2011) [Eksport na wschód opłacalny dla polskich firm, 2012] were carried out using a completely different facility: the Bank financed the foreign buyer who employed a Polish contractor. The hotel in Edinburgh is an equity investment of the Polish enterprise, however, the Polcom Group acts as an exporter and investor at the same time. An analogous facility was applied in the second foreign project of Polcom - a hotel at Luton airport near London [Polcom ma hotel w Edynburgu, 2017].

\section{Summary}

Internationalisation of Polish companies achieved through growing exports and foreign direct investment provides an important impulse for the growth of the Polish economy. Recently, BGK has expanded its product offer in the area of official support to foreign activities of Polish enterprises. It has exerted a positive impact on increases in export financing and foreign investment, as well as on the number of countries in which the Bank has supported domestic companies. Examples of transactions financed by BGK presented in this paper demonstrate that, in cooperation with the KUKE, BGK may boost the opportunities for bigger openness of Polish companies to foreign markets and change the structure of exports to ensure smaller dependence on the EU member states.

\section{References}

\section{Books and papers}

1. Andrzejak, M. (2017). Program gwarancyjny de minimis jako inicjatywa zwalczania barier dostępu do kapitału dla MSP. Zeszyty Naukowe Państwowej Wyższej Szkoły Zawodowej w Płocku. No. 25/2017, pp. 79-90.

2. Barłożewski, K. (2017). Wpływ ekspansji zagranicznej na efektywność przedsiębiorstw. Warszawa: C.H. Beck.

3. Cavusgil Tamer, S., Knight G., Reisenberger J. (2017). International Business: the new realities. Essex, UK: Pearson.

4. Frańczuk, M. (2017). Gwarancja de minimis jako sposób na zwiększenie dostępności do kredytów dla mikro, małych i średnich przedsiębiorstw. [In:] Monografie Politechniki Lubelskiej "Otoczenia a wartość biznesu". M. Miszczuk, M. Sosińska-Wit (Eds.) Lublin: Politechnika Lubelska. 
5. Ciszewska-Mlinaric, M., Obłój, K. (2014). Systemowe efekty umiędzynarodowienia polskich firm. [In:] Zarzadzanie i polityka gospodarza dla rozwoju, G.W. Kołodko (Ed.), Warszawa: Poltext.

6. Jarosiński, M. (2013). Procesy i modele internacjonalizacji polskich przedsiębiorstw. Warszawa: SGH.

7. Johanson, J., Vahlne, J.-E. (1977). The Internationalization process of the firm - a model of knowledge development and increasing foreign market commitments. Journal of International Business Studies, No. 8(1).

8. Johanson, J. I Vahlne, J.-E. (2009). The Uppsala internationalization process model revisited: from liability of outsidership. Journal of International Business Studies, No. 40(9).

9. Karasiewicz, G. (2013). Marketingowe strategie internacjonalizacji polskich przedsiębiorstw. Warszawa: Wolters Kluwer Polska.

10. Oczkowska, R. (2013). Międzynarodowa ekspansja przedsiębiorstw w warunkach globalizacji. Motywy-strategie - tendencje. Warszawa: DIFIN.

11. Rymarczyk, J. (Ed.) (2017). Handel Zagraniczny. Warszawa: PWE.

12. Rymarczyk, J. (2012). Biznes międzynarodowy. Warszawa: PWE.

13. Rymarczyk, J. (2004). Internacjonalizacja i globalizacja przedsiębiorstwa. Warszawa: PWE.

14. Witek-Hajduk, M. (2009). Motywy internacjonalizacji polskich średnich i dużych przedsiębiorstw. [In:] Współczesne problemy międzynarodowej działalności przedsiębiorstw, research papers. J. Schroeder, B. Stępień (Eds.), Zeszyt naukowy, No. 125, Poznań: Wyd. Uniwersytetu Ekonomicznego w Poznaniu.

\section{Internet sources}

1. Bank Światowy (2019). Exports of goods and services (\%GDP). Retrieved from: https://data. worldbank.org/indicator/\%20NE.EXP.GNFS.ZS [accessed: 17.04.2019].

2. BGK. Communication of 15.06.2015. Retrieved from: https://www.bgk.pl/aktualnosci/grupaboryszew-pozyskala-finansowanie-bgk-na-rozwoj-grupy-maflow-826/

3. BGK. Communication of 22.02.2018. Retrieved from: https://www.bgk.pl/biuro-prasowe/ komunikaty-prasowe/bgk-sfinansuje-kontrakt-rafako-w-indonezji-2243/

4. BGK. Communication of 11.03.2019. Retrieved from: https://media.bgk.pl/53903-pierwszypolsko-ukrainski-wykup-wierzytelnosci-umowa-bgk-i-feerum-na-30-25-mln-eur

5. BGK. Annual Report for 2014. Retrieved from: https://www.bgk.pl/files/public/Pliki/O_Banku/ Bank_w_liczbach/Raport_roczny/Raport_roczny_BGK_za_2014_r.pdf

6. BGK. Annual Report for 2015. Retrieved from: https://www.bgk.pl/files/public/Pliki/O_Banku/ Bank_w_liczbach/Raport_roczny/Raport_roczny_BGK_za_2015_r.pdf

7. BGK. Annual Report for 2016. Retrieved from: https://www.bgk.pl/files/public/uploads/graphics/Raport_roczny_BGK_za_2016_r..pdf

8. BGK. Annual Report for 2017. Retrieved from: https://www.bgk.pl/files/public/uploads/graphics/Raport_roczny_BGK_za_2017_r.pdf

9. Business Insider (2017). Firma z Chojnic podbija światowe rynki. Otworzyła hotel Marriott w Edynburgu, a następnym celem serce Londynu, published on 23.11.2017. Retrieved from: https://businessinsider.com.pl/firmy/polcom-otwiera-hotel-w-edynburgu/t8 s3qrf 
10. CEB (Ceska Exportni Banka). Annual Report for 2017. Retrieved from: https://www.ceb. cz/_sys_/FileStorage/download/3/2314/vz_en_17_fin_cd.pdf

11. Eurostat (2017). Wages and Labour Costs. Retrieved from: http://ec.europa.eu/eurostat/statistics-explained/index.php/Wages_and_labour_costs/pl, accessed 10.04.2019

12. GUS (2018). Działalność podmiotów posiadających jednostki zagraniczne w 2016 roku, published on 27.04.2018. Retrieved from: https://stat.gov.pl/obszary-tematyczne/podmioty-gospodarcze-wyniki-finansowe/przedsiebiorstwa-niefinansowe/dzialalnosc-podmiotow-posiadajacychjednostki-zagraniczne-w-2016-roku,5,9.html

13. GUS (2018a), Rocznik statystyczny handlu zagranicznego 2018, published on 31.10.2018. Retrieved from: https://stat.gov.pl/obszary-tematyczne/roczniki-statystyczne/roczniki-statystyczne/rocznik-statystyczny-handlu-zagranicznego-2018,9,12.html

14. GUS (2018b). Informacja Głównego Urzędu Statystycznego w sprawie skorygowanego szacunku produktu krajowego brutto za 2017 rok, published on 03.10.2018. Retrieved from: https://stat. gov.pl/obszary-tematyczne/rachunki-narodowe/roczne-rachunki-narodowe/informacjaglownego-urzedu-statystycznego-w-sprawie-skorygowanego-szacunku-produktu-krajowegobrutto-za-2017-rok,9,4.html

15. GUS (2019). Obroty towarowe handlu zagranicznego ogółem i według krajów w okresie styczeń - grudzień 2018 r., temporary data published on 11.02.2019., Retrieved from: https://stat.gov. $\mathrm{pl} /$ obszary-tematyczne/ceny-handel/handel/obroty-towarowe-handlu-zagranicznego-ogolemi-wedlug-krajow-w-okresie-styczen-grudzien-2018-roku,1,77.html

16. KUKE. Communication of 07.04.2017. Retrieved from: http://www.kuke.com.pl/aktualnosci/ bgk-zapewnia-finansowanie-kontraktu-eksportowego-do-gruzji-kuke-zabezpiecza-kredyt-,44. html

17. KUKE. Communication of 15.12.2016. Retrieved from: http://www.kuke.com.pl/aktualnosci/ bgk-i-kuke-finansuja-kontrakt-eksportowy-firmy-unibep-sa,35.html

18. KUKE. Communication of 07.04.2017. Retrieved from: https://www.kuke.com.pl/aktualnosci/ bgk-zapewnia-finansowanie-kontraktu-eksportowego-do-gruzji-kuke-zabezpiecza-kredyt-,44. html

19. MEIB, Magyar Export-Import Bank. Investor Presentation, June 2017. Retrieved from: https:// exim.hu/en/for-investors/rating/investor-presentation/file

20. Ministerstwo Finansów RP. Retrieved from: http://www.finanse.mf.gov.pl/wspieranie-eksportu/ kredyty-eksportowe [accessed: 31.03.2019].

21. NBP (2018a). Polskie inwestycje bezpośrednie za granica w 2017 r.. Retrieved from: http://www. nbp.pl/publikacje/pib/pib_2017_n.pdf [accessed: 31.03.2019].

22. NBP [2018b]. Zagraniczne inwestycje bezpośrednie w Polsce i polskie inwestycje bezpośrednie za granica w 2017 roku. Retrieved from: https://www.nbp.pl/publikacje/ib_raporty/raport_ib_2017. pdf [accessed: 04.04.2019].

23. OT Logistics S.A. Communication of 18.09.2017. Retrieved from: http://otlogistics.com.pl/ aktualnosci/ot-logistics-przejmie-kontrole-operacyjno-finansowa-nad-chorwackim-portem -dzieki-porozumieniu-akcjonariuszy/

24. Puls Biznesu. Polcom ma hotel w Edynburgu, published on 22.11.2017. Retrieved from: https:// www.pb.pl/polcom-ma-hotel-w-edynburgu-898999 
25. Puls Biznesu. Nowe rynki pod polską flagą, published on 29.03.2017. Retrieved from: https:// www.pb.pl/na-nowe-rynki-pod-polska-flaga-858019

26. Rafako S.A. Raport Bieżacy 66/2017 of 29.12.2017. Retrieved from: https://www.rafako.com. pl/pub/File/raporty_biezace/2017/RB_66_2017_UMOWA_LOMBOK_FINAL.pdf

27. Rzeczpospolita. OT Logistics przejmuje chorwacki port, published on 07.09.2017. Retrieved from: http://www.rp.pl/Biznes/309079893-OT-Logistics-przejmuje-chorwacki-port.html

28. Rzeczpospolita. Eksport na Wschód opłacalny dla polskich firm, published on 06.02.2012. Retrieved from: https://www.rp.pl/artykul/807289-Eksport-na-Wschod-oplacalny-dlapolskich-firm.html

29. WTO (2017). World Trade Statistical Review 2017. Retrieved from: https://www.wto.org/ english/res_e/statis_e/wts2017_e/wts2017_e.pdf

30. Unibep S.A. Current Report 46/2016. Retrieved from: http://unibep.pl/relacje-inwestorskie/ raporty/raporty-biezace/35-2016/2118-46-2016-aktualizacja-informacji-nt-zawarcia-przezunibep-umowy-na-realizacje-centrum-handlowego-w-grodnie-w-republice-bialorus.html

31. Unibep S.A. Current Report No. 12/2017. Retrieved from: http://unibep.pl/relacje-inwestorskie/ raporty/raporty-biezace/133-2017/2176-12-2017-aktualizacja-informacji-nt-umowy-narealizacje-centrum-handlowego-w-grodnie-w-republice-bialorus.html

\section{Legal documents}

1. OECD. Arrangement on Officially Supported Export Credits, 1 January 2019, TAD/PG (2019) 1.

2. Uchwała z dnia 8 czerwca 2001 (Act of 8 June 2001) o dopłatach do oprocentowania kredytów eksportowych o stałych stopach procentowych. 